\title{
COMPETITIVENESS IN RICE PRODUCTION IN OSUN STATE, NIGERIA: THE POLICY ANALYSIS MATRIX APPROACH
}

\author{
Rabirou Kassali ${ }^{\bowtie}$, Lateef Olatunbosun Jimoh ${ }^{1}$ \\ ${ }^{1}$ Obafemi Awolowo University, Nigeria
}

\begin{abstract}
This study assessed the competitiveness of rice production under different varietal technologies in Osun State. A multistage sampling technique was adopted to select the respondents for the study. Both primary and secondary data, including prices of inputs and outputs, rice yields, import tariff, transportation cost, port loading and unloading charges and official exchange rate, foreign exchange premium, etc., were collected and analyzed using descriptive statistics and the Policy Analysis Matrix (PAM) approach. The results revealed that effective protection coefficients (EPC) for the three identified rice varieties (Local, FARO53 and FARO54) were 0.89, 0.98 and 0.97 , respectively. The Domestic Resource Cost (DRC) was 0.84, 0.48 and 0.48; the Nominal Protection Coefficient (NPC) on tradable inputs and outputs was $0.89,0.98$ and 0.97; while the Social Cost Benefit (SCB) was 0.85, 0.52 and 0.52 for the three varietal technologies, respectively. The results indicate that rice farmers using the three varieties have a comparative advantage $(\mathrm{DRC}<1)$ in rice production in the study area, and the two improved varieties provided a greater competitiveness. The study concluded that Osun State has a comparative advantage in rice production under the import parity prices regime which, however, is not true under the assumptions of export parity.
\end{abstract}

Keywords: rice varieties, comparative advantage, private and social profitability, policy analysis matrix

\section{INTRODUCTION}

Nigeria is a developing country with an agricultural sector that has been playing a prominent role in the growth of the national economy till the advent of oil in the 1970s. The agricultural sector, which employs about 70 percent of the population, provides the bulk of the country's food needs. The sector supplies food crops ranging from cereals to legumes and tubers which are of considerable importance for the rural economy and national food security (Tsegai and Kormawa, 2009). Rice, a cereal which accounts for a greater share of the national food basket, is among the staple food crops that have risen in importance in recent years in the country (Akande, 2002; UNEP, 2005).

In Nigeria, rice is mostly produced by smallholder farmers with yields averaging 1.8 tons per ha, far below the world average of $4.1 \mathrm{mt} / \mathrm{ha}$ (Babatunde et al., 2017). The sub-sector is characterized by high costs of production and processing, with annual imports volume standing at about 4,500 million tons (USDA, 2015). Recently, to reduce the current level of imports and the associated huge import bill, and to encourage local production, the Federal Government has introduced a series of trade policies ranging from imposition of import duties and levies (up to $70 \%$ in 2014) to a total ban on imports through land borders.

The low yields of traditional rice production systems have led to the introduction of new rice varieties to

$\bowtie$ PhD Rabirou Kassali, Department of Agricultural Economics, 220282, Obafemi Awolowo University, Ile-Ife, Osun State, Nigeria, e-mail: kasskassali@yahoo.com, https://orcid.org/0000-0002-1210-5323 
boost production, enhanced with appropriate processing technologies and marketing policies. The goal was to close the gap between demand and supply and to improve the country's self-sufficiency in rice production. But the present nature of profitability and competitiveness of these technologies remains unknown, meaning uncertainty still surrounds the profitability of rice production technologies for both the farmers and the country, despite the availability of a suitable environment for the development of the crop in various agro-ecological zones.

\section{RESEARCH PROBLEM}

The rapidly growing population and consequent increase in demand for food beyond supply levels has created a local supply deficit resulting in changing the consumption patterns among Nigerian households (FOS, 2000). On average, Nigeria spends USD 300 million per year on rice imports to satisfy the national demand, despite the existence of favorable agro-ecological conditions for the production of the commodity across the country.

Production strategies for increasing rice production include:

- availability of suitable lands (upland, rain-fed, lowland, swampy or irrigated land),

- possibility of using more than one (double, triple) cropping systems,

- availability of suitable rice technologies.

In recent years, improved rice varieties developed by international research centers such as WARDA (now Africa Rice), IRRI, etc., have been introduced in different zones of the country, supported by huge investments in processing, storage and marketing, and yet there is no commensurate increase in supply as expected. The most recent effort is the introduction of a friendly rice sector policy to encourage more private participation in the rice value chain, so as to stimulate local production. Of note is the massive introduction of different technological packages with large amounts of extension services. However, the production continues to lag behind demand. It is therefore urgent to find out: how competitive is rice production in the study areas? What are the effects of recent policy measures on rice production? Would rice production be financially and socially profitable for the private and national economy at large and can actual production be improved?
Studies such as Ogbe et al. (2011) reported that the production of rice in all the Nigerian agro-ecological zones assessed was economically viable and provided a comparative advantage. Using the PAM method, Ugochukwu and Ezedinma (2011) found out that the three rice production systems in Eastern Nigeria are profitable; the double rice cropping system gives the highest profit, followed by rice produced in lowland systems, even though price distortions discriminate against growing the crop in the lowland rice ecology. Therefore, in view of the huge import bill spent on rice, and the availability of favorable conditions for growing the crop in Nigeria in general - and Osun State in particular - this study intends to assess the nature of competitiveness of Osun State in rice production. The main objective of this study was to assess the efficiency and profitability of rice production in Osun State. The study will also help identify the most lucrative and competitive rice varietal technologies that can quickly improve food security in the country.

\section{METHODOLOGY}

\section{Study area}

The study was carried out in Osun State, in southwestern part of Nigeria, in the guinea savannah and rainforest agro-ecological zones. The area is located at latitudes between $7^{\circ}$ and $8^{\circ} \mathrm{N}$ and between longitudes $4^{\circ}$ and $5^{\circ} \mathrm{E}$. The state is bounded by Ogun State in the south, Kwara State in the north, Ondo and Ekiti States in the east and Oyo State in the west. The State enjoys a tropical climate with bimodal rainfall patterns. The rainy season generally occurs between March and October while the dry season occurs between November and February, with an annual rainfall ranging between $800 \mathrm{~mm}$ in the Savannah agro-ecology to $1,500 \mathrm{~mm}$ in the rainforest. The annual temperature varies between $26^{\circ} \mathrm{C}$ and $27^{\circ} \mathrm{C}$. The mean monthly relative humidity is $61 \%$ and $83 \%$ for the early and late planting seasons, respectively.

The State is sub-divided into three Agricultural Zones (OSSADEP, 1993), namely Iwo, Ife/Ijesha and Oshogbo. Each zone is further sub-divided into blocks and each block into cells. The tropical climate in the area favors the growth of some annual crops including yam, cassava, maize, rice, cowpea, plantain and bananas and tree crops such as cocoa, kola nut and oil palm. The climatic condition is suitable for rice cultivation. According to Shobowale (2000), common rice varieties 
grown in the State include the old Osogbo rice and the improved upland FARO varieties.

\section{Sampling technique}

A multi-stage sampling technique was adopted in selecting the respondents. The first stage was the selection of all three agro-ecological zones of the State. The second stage was the purposive selection of two (2) Local Government Areas (LGAs) from each of the three zones where rice production is predominant. The third stage was the selection of five (5) major rice growing villages from each of the selected LGAs. The last stage was a random selection of five (5) rice farmers from the list of rice growers in each village, making a total of 150 respondents for the study. The extension services helped establish the list of rice growers and facilitated their full cooperation. A replacement took place whenever a farmer was unable to participate in the survey.

\section{Data collection}

Primary and secondary data was used for this study. Primary data was collected with the use of a well structured questionnaire. Information collected includes rice varieties used, rice farm size, inputs (labor, seeds, fertilizers, pesticides), prices, rice output harvested, local market and farm gate prices, transportation, processing, storage and marketing charges, etc. Secondary data includes Cost, Insurance and Freight (CIF) and Free On Board (FOB) prices, exchange rate, foreign exchange premium, port charges, loading/unloading costs, level of subsidy, tax, and import/export tariffs, as sourced from the Central Bank of Nigeria (CBN), National Bureau of Statistics (NBS), and the Customs Services, respectively.

\section{Data analysis}

Descriptive statistics tools were used to analyze the data. These include frequency counts, percentages and means. Three economic efficiency indicators of the policy analysis matrix were used to assess the competitiveness of the identified rice technologies used in the area under review, including the Nominal Protection Coefficient (NPC) and Effective Protection Coefficient (EPC). NPC is the ratio of the private price of a commodity to its social price. It measures the extent of policy effect on output or the divergence between private and social prices resulting from policy impacts or market failures. EPC assesses whether the government's policy tends to tax or protect consumers and producers.
The financial competitiveness and comparative advantage of various rice technologies was analyzed based on three measures of profitability, the Net Private Profitability (NPP), which is the profit evaluated at market prices; the Net Social Profitability (NSP) defined as the profit evaluated at social prices (private prices corrected for distortions) at both output and input levels; and Domestic Resource Cost (DRC) referred to as the ratio of costs of non-tradable resources at social prices to the value added at social prices.

Table 1 presents the PAM model used for the analysis. Averages of revenues, tradable input costs, non-tradable input costs excluding land, and profits were determined at private and social prices using farm budget figures. Once calculated, they were used to form the Policy Analysis Matrix (PAM) for the commodity concerned. The bottom row, labeled "divergences" or "policy effect," defines the differences between first-row (private) entries and second-row (social) entries.

Table 1. Policy analysis matrix

\begin{tabular}{lcccc}
\hline \multicolumn{1}{c}{ Items } & Revenue & $\begin{array}{c}\text { Tradable } \\
\text { inputs cost }\end{array}$ & $\begin{array}{c}\text { Non-tradable } \\
\text { inputs cost }\end{array}$ & Profit \\
\hline Private & A & B & C & D \\
Social & E & F & G & H \\
Policy effect & I & J & K & L \\
\hline
\end{tabular}

Source: Monke and Pearson, 1989.

\section{Policy indicators derived from the matrix Measures of policy incentives}

Private profits $(D)=A-(B+C)$; net profits of the farmer.

Social profits $(H)=E-(F+G)$; net profits of the society. Output transfers $(\mathrm{I})=\mathrm{A}-\mathrm{E}$; extent of government policy distortion of the product market.

Input transfers $(\mathrm{J})=\mathrm{B}-\mathrm{F}$; tradable input transfers from the farmer to the society.

Factor transfers $(\mathrm{K})=\mathrm{C}-\mathrm{G}$; non-tradable input transfers from the farmer to the society.

Net transfers $(\mathrm{L})=\mathrm{D}-\mathrm{H}$ or $\mathrm{I}-\mathrm{J}-\mathrm{K}$; net effects of policy distortion on both input and output markets.

$\mathrm{NPC}=\mathrm{A} / \mathrm{E}$; ratio of domestic producer price to equivalent world price, adjusted by exchange rates, transportation costs and other taxes and tariffs. NPC $>1$ means government protection of the output market. 
$\mathrm{EPC}=(\mathrm{A}-\mathrm{B}) /(\mathrm{E}-\mathrm{F}) ;$ ratio of value added at domestic and border prices. EPC $>1$ indicates protection of output and tradable input markets. This shows the extent of government subsidies on those markets.

\section{Measures of comparative advantage}

$\mathrm{DRC}=\mathrm{G} /(\mathrm{E}-\mathrm{F}) ;$ if $\mathrm{DRC}<1$, a comparative advantage exists. It means that the use of domestic resources in the production of rice adds more value than they cost the society.

$\mathrm{SCB}=(\mathrm{F}+\mathrm{G}) / \mathrm{E}$; if $\mathrm{SCB}<1$, all inputs (both tradable and non-tradable) add more value than they cost the society.

$\mathrm{NPP}=\mathrm{A}-\mathrm{B}-\mathrm{C}=\mathrm{D}$ [without land use cost $]$; if $\mathrm{NPP}>0$, rice production is profitable to the rice farmer.

$\mathrm{NSP}=\mathrm{E}-\mathrm{F}-\mathrm{G}=\mathrm{H}$ [without land use cost]; if $\mathrm{NSP}>0$, rice production is profitable to the society.

Profitability Coefficient $(\mathrm{PC})=(\mathrm{A}-\mathrm{B}-\mathrm{C}) /(\mathrm{E}-\mathrm{F}-\mathrm{G})$ or $\mathrm{D} / \mathrm{H}$; if $\mathrm{PC}>1$, there are net transfers from the society to private businesses.

\section{RESULTS AND DISCUSSION}

\section{Distribution of rice varieties grown in the area}

Table 2 shows the distribution of rice varieties grown in the State's three agricultural zones, listed in order of importance: FARO53 (45\%), followed by local variety (35\%), FARO54 (18\%) and lastly the newly introduced NERICA 1 ( $2 \%$ only). The results also indicated that the local variety was mostly used in the Ife/Ijesa zone;
FARO53 was mostly adopted in the Iwo zone; while both improved varieties FARO53 and FARO54 are the mostly (and equally) used varieties in the Osogbo zone. Therefore, the analysis conducted in this study covers three predominant varieties found in the areas, namely: the local rice variety, FARO53 and FARO54.

\section{Profitability analysis of rice varieties}

The PAM analysis for the three rice varieties is presented in Table 3. Of note is the negative value of divergences which suggests the three most widely adopted rice technologies in the area offer a greater social profitability. In other words, the output taxation and input subsidies result in a greater social profitability for all the rice technologies.

\section{Policy incentives and competitiveness in rice production}

Table 4 presents the derived values of economic efficiency indicators for the three most widely adopted varietal technologies: the Nominal Protection Coefficient (NPC), the Effective Protection Coefficient (EPC) and the Domestic Resource Cost (DRC). Likewise, financial competitiveness indicators, the Social Cost Benefit (SCB), Net Private Profitability (NPP) and Net Social Profitability (NSP), were also presented.

The NPC values of 1.122, 0.976 and 0.974 for the respective technologies show that the farmers were implicitly taxed on the product, except for the local variety. The EPC values also indicate that the overall impact of policy measures resulted in a net disincentive to produce

Table 2. Distribution of identified varieties of rice grown in the area

\begin{tabular}{lccccccc}
\hline \multirow{2}{*}{ Rice variety } & \multicolumn{2}{c}{ Ife/Ijesa zone } & \multicolumn{2}{c}{ Iwo zone } & \multicolumn{2}{c}{ Osogbo zone } & Osun State \\
\cline { 2 - 6 } & freq. & perc. $(\%)$ & freq. & perc. $(\%)$ & freq. & perc. (\%) & $(\%)$ \\
\hline Local & 45 & 90 & 05 & 10 & 03 & 06 & 35 \\
Nerica 1 & 03 & 06 & - & - & - & - & 02 \\
FARO53 & 02 & 04 & 43 & 86 & 23 & 46 & 45 \\
FARO54 & - & - & 02 & 04 & 24 & 48 & 18 \\
Total & & 100 & & 100 & & 100 & 100 \\
\hline
\end{tabular}

Source: field survey, 2015. 
Kassali, R., Jimoh, L. O. (2018). Competitiveness in rice production in Osun State, Nigeria: the Policy Analysis Matrix approach. J. Agribus. Rural Dev., 2(48), 129-136. http://dx.doi.org/10.17306/J.JARD.2018.00411

Table 3. PAM result per ha for all three rice varietal technologies (NGN)

\begin{tabular}{lcccc}
\hline \multicolumn{1}{c}{ Rice variety } & Revenue* & Tradable inputs & Non-tradable inputs & Profit \\
\hline Local & & & & \\
\hline Private value & $113,765.27$ & $7,269.68$ & $96,295.27$ & $10,200.32$ \\
Social value & $101,415.60$ & $7,462.70$ & $78,568.34$ & $15,384.56$ \\
Policy effect & $12,349.67$ & -193.02 & $17,726.93$ & $-5,184.24$ \\
\hline FARO 53 & & & & \\
\hline Private value & $172,674.95$ & $11,006.08$ & $98,015.37$ & $63,653.50$ \\
Social value & $176,984.56$ & $11,388.52$ & $80,204.31$ & $85,391.73$ \\
Policy effect & $-4,309.61$ & -382.44 & $17,811.06$ & $-21,738.23$ \\
\hline FARO 54 & & & & \\
\hline Private value & $162,676.98$ & $10,528.96$ & $92,388.35$ & $59,759.67$ \\
Social value & $166,930.08$ & $10,903.93$ & $75,661.70$ & $80,364.45$ \\
Policy effect & $-4,253.10$ & -374.97 & $16,726.65$ & $-20,604.78$ \\
\hline
\end{tabular}

* Naira, Nigerian currency.

Source: data analysis, 2015.

Table 4. Summary results of PAM indicators for all three rice varieties

\begin{tabular}{lcccccc}
\hline \multirow{2}{*}{ Rice variety } & \multicolumn{5}{c}{ Indicators } \\
\cline { 2 - 7 } & NPC & EPC & DRC & SCB & NPP & NSP \\
\hline Local & 1.122 & 1.133 & 0.836 & 0.848 & 10200.32 & 15384.56 \\
FARO53 & 0.976 & 0.976 & 0.484 & 0.518 & 63653.50 & 85391.73 \\
FARO54 & 0.974 & 0.975 & 0.484 & 0.578 & 59759.67 & 80364.45 \\
\hline
\end{tabular}

Source: data analysis, 2015.

the commodity, especially the improved varieties. Besides, this result confirms that the local rice enjoys a better market price among the local population. However, the table shows that all the enterprises were profitable and - judging from the DRC, NPP and NSP values had a comparative advantage. Nevertheless, the average profits per hectare were far from being at their social potential for all three technological varieties. The social profits per hectare offered by alternative technologies imply that every hectare under cultivation added value to the economy of the State and the country at large. This result is confirmed by Ogbe et al. (2011).
Effects of policy changes on economic profitability of varietal technologies (sensitivity analysis)

These effects were determined from the basic budget table used to generate new PAM tables. On that basis, the policy incentives and comparative advantage indicators (as shown in Tables 5,6 and 7) were calculated. The sensitivity analysis covered the FOB prices, yield, output price, and prices of tradable and non-tradable inputs. Thus, the three tables generated show the effects of a change in policy on the economic profitability of each of the technologies. As shown in Table 5, a 15\% 
Kassali, R., Jimoh, L. O. (2018). Competitiveness in rice production in Osun State, Nigeria: the Policy Analysis Matrix approach. J. Agribus. Rural Dev., 2(48), 129-136. http://dx.doi.org/10.17306/J.JARD.2018.00411

Table 5. Impact of changes in FOB prices on comparative advantage

\begin{tabular}{|c|c|c|c|c|c|c|c|c|c|c|}
\hline \multirow{4}{*}{ Rice variety } & \multirow{3}{*}{\multicolumn{2}{|c|}{ Present situation }} & \multicolumn{8}{|c|}{ Changes in FOB } \\
\hline & & & \multicolumn{4}{|c|}{ FOB down } & \multicolumn{4}{|c|}{ FOB up } \\
\hline & & & \multicolumn{2}{|c|}{$15 \%$} & \multicolumn{2}{|c|}{$30 \%$} & \multicolumn{2}{|c|}{$15 \%$} & \multicolumn{2}{|c|}{$30 \%$} \\
\hline & priv. & soc. & priv. & soc. & priv. & soc. & priv. & soc. & priv. & soc \\
\hline Local & + & + & + & + & + & - & + & + & + & + \\
\hline FARO53 & + & + & + & + & - & - & + & + & + & + \\
\hline FARO54 & + & + & + & + & - & - & + & + & + & + \\
\hline
\end{tabular}

Source: field survey, 2015.

decrease in price of outputs does not have a considerable impact on economic profitability of the three technologies. However, with a $30 \%$ decrease, all technologies became economically non profitable. A $15 \%$ decrease in FOB prices still makes all technologies (local and improved) privately and socially profitable. But if the FOB prices are reduced by $30 \%$, all technologies become socially non profitable. However, the local variety maintains its private profitability even at a $30 \%$ decrease in
FOB prices. In contrast, when FOB prices move up, all technologies become privately and socially profitable. In Table 6, a decrease in yield and output price by $30 \%$ results in a loss of competitiveness in all three technologies $(\mathrm{SCB}>1$; $\mathrm{DRC}>1)$. Table 7 shows that the effects of the increase in labor costs are similar to the impacts of a decrease in FOB prices while the impacts of reducing the fertilizers' CIF price are similar to those observed under the assumption of an increase in FOB prices.

Table 6. Impact of change in yield and output price

\begin{tabular}{|c|c|c|c|c|c|c|c|c|c|}
\hline \multirow[b]{2}{*}{ Indicator } & \multicolumn{3}{|c|}{ Local } & \multicolumn{3}{|c|}{ Faro53 } & \multicolumn{3}{|c|}{ Faro54 } \\
\hline & $\begin{array}{l}\text { present } \\
\text { situation }\end{array}$ & $\begin{array}{c}30 \% \\
\text { decrease }\end{array}$ & $\begin{array}{c}30 \% \\
\text { increase }\end{array}$ & $\begin{array}{l}\text { present } \\
\text { situation }\end{array}$ & $\begin{array}{c}30 \% \\
\text { decrease }\end{array}$ & $\begin{array}{c}30 \% \\
\text { increase }\end{array}$ & $\begin{array}{l}\text { present } \\
\text { situation }\end{array}$ & $\begin{array}{c}30 \% \\
\text { decrease }\end{array}$ & $\begin{array}{c}30 \% \\
\text { increase }\end{array}$ \\
\hline $\mathrm{SCB}$ & 0.85 & 1.50 & 0.44 & 0.52 & 1.06 & 0.03 & 0.52 & 1.05 & 0.31 \\
\hline DRC & 0.84 & 1.58 & 0.41 & 0.48 & 1.06 & 0.03 & 0.48 & 1.06 & 0.28 \\
\hline
\end{tabular}

Source: field survey, 2015.

Table 7. Change in costs of non-tradable and tradable inputs

\begin{tabular}{lccccccccc}
\hline \multirow{2}{*}{ Indicator } & \multicolumn{3}{c}{ Local } & \multicolumn{3}{c}{ Faro53 } & \multicolumn{3}{c}{ Faro54 } \\
\cline { 2 - 18 } & $\begin{array}{c}\text { present } \\
\text { situation }\end{array}$ & $\begin{array}{c}30 \% \\
\text { decrease }\end{array}$ & $\begin{array}{c}30 \% \\
\text { increase }\end{array}$ & $\begin{array}{c}\text { present } \\
\text { situation }\end{array}$ & $\begin{array}{c}30 \% \\
\text { decrease }\end{array}$ & $\begin{array}{c}30 \% \\
\text { increase }\end{array}$ & $\begin{array}{c}\text { present } \\
\text { situation }\end{array}$ & $\begin{array}{c}30 \% \\
\text { decrease }\end{array}$ & $\begin{array}{c}30 \% \\
\text { increase }\end{array}$ \\
\hline SCB & 0.85 & 1.50 & 0.19 & 0.52 & 0.36 & 0.67 & 0.52 & 0.36 & 0.67 \\
DRC & 0.84 & 0.57 & 0.11 & 0.48 & 0.57 & 0.64 & 0.48 & 0.33 & 0.64 \\
\hline
\end{tabular}

Source: field survey, 2015. 


\section{CONCLUSION}

The study shows that rice production in its three most widely adopted technologies is financially profitable in the study area. A positive Net Private Profitability indicates that rice farmers are provided with an incentive to produce rice with the current technologies. Also, all production technologies are socially profitable $(\mathrm{NSP}>0)$, which means the country has a comparative advantage in rice production. The tradable input and output transfers were negative, indicating the existence of both input subsidies and output taxation, especially for the two improved rice technologies. For all the technologies, the competitiveness coefficients for DRC and SCB values are positive and less than one, suggesting that farmers in Osun state have a comparative advantage in all the three most used varietal technologies, making rice a good strategy for import substitution in the area. The highest comparative advantage is seen in the two improved rice varieties FARO53 and FARO54 (both having the lowest computed DRC and SCB values). The negative signs of net policy effect for all the technologies show that various government interventions have had a positive impact on economic efficiency, financial competitiveness and social profitability of domestic rice production. In addition, with respect to revenue, improved rice variety technologies give the highest revenue, which seems to be optimized under FARO53. The NPP and NSP values per hectare for all the alternative technologies are very high. These values also confirm that Osun State has a comparative advantage in rice production.

The PAM analysis of economic efficiency of alternative technologies in the study area indicates that most of inputs used are yet to be optimized; and that optimum yield was also not attained. As regards the financial competitiveness analysis under export parity assumptions for all three technologies, the results show that social profits are negative and competitiveness coefficients are more than one (i.e. $\mathrm{DRC}=1.58,1.06$ and 1.06; $\mathrm{SCB}=1.50,1.06$ and 1.05 , respectively). This means that under export parity condition, Osun State does not have a comparative advantage in rice production. The sensitivity analysis of the PAM with a 30 percent increase and a 30 percent decrease in yield and border price shows a similar pattern of competitiveness coefficients for all three technologies.
In order to enhance both productivity and efficiency in the rice sub-sector in Osun State, the following recommendations are proffered:

- In view of the existing comparative advantage in rice production, the current policy of food sufficiency in rice should be pursued in order to reduce imports. In addition to implementing the government's import substitution policy, there is need to reduce taxation on output and subsidy levels on inputs so as to create greater profitability for farmers and increase productivity;

- The development and availability of improved seeds; extension and training; and processing and marketing infrastructure should further be encouraged to support current rice development programs in the State;

- Stable macroeconomic measures - with a less volatile exchange rate policy - should be enforced to stimulate and sustain private participation for a full development of the rice value chain.

\section{ACKNOWLEDGEMENTS}

The authors would like to acknowledge and thank Mr. Omisore, Director of OSSADEP, Iwo, for providing the list of and facilitating contacts with rice farmers; and Mr. Lukman Oyebode, Student at Polytechnic, Iree, and Mrs. Jimoh Afusat, for assisting in the data collection process.

\section{REFERENCES}

Akande, T. (2002). An Overview of the Nigeria Rice Economy. Monograph Series. Nigerian Institute of Social and Economic Research (NISER) Ibadan.

Babatunde, R. O., Salami, M. F., Muhammed, B. A. (2017). Determinants of yield gap in rainfed and irrigated rice production systems - evidence from household survey in Kwara State, Nigeria. J. Agribus. Rural Dev., 1(43), 2533. http://dx.doi. org/10.17306/J.JARD.2017.00286

FOS [Federal Office of Statistics] (2000). Annual Abstract of Statistics, Lagos, P.2.

IRRI [International Rice Research Institute] (2001). Rice Statistics. Retrieved Feb $15^{\text {th }} 2014$ from: https://oryza.com/

Monke, E., Pearson, S. (1989). The Policy Analysis Matrix for Agricultural Development. Cornell University Press. Ithaca, and London. 
Kassali, R., Jimoh, L. O. (2018). Competitiveness in rice production in Osun State, Nigeria: the Policy Analysis Matrix approach. J. Agribus. Rural Dev., 2(48), 129-136. http://dx.doi.org/10.17306/J.JARD.2018.00411

Ogbe, A. O., Okoruwa, V. O., Saka, O. J. (2011). Competitiveness of Nigerian Rice and Maize Production Ecologies: A Policy Analysis Approach. Tropic. Subtropic. Agro Ecos., 14, 493-500.

Osun State Agricultural Development Programme (OSSADEP) (1993). Report of Survey on Rice. Agricultural Extension Department. Iwo, Osun State, Nigeria: OSSADEP.

Shobowale, O. J. (2000). Towards Developing A Coordinated Rice Seed Production. National Seed Service. (Mimeographed, Ibadan). Appl. Tropic. Agric., 2(2), 152-159.

Tsegai, D. W., Kormawa, P. M. (2009). The determinants of urban households demand for cassava and cassava products in Kaduna, Northern Nigeria: An application of the AIDS model. Eur. J. Dev. Res., 2, 435-447.

Ugochukwu, A. I., Ezedinma, C. I. (2011). Intensification of Rice Production Systems in Southeastern Nigeria: A Policy Analysis Matrix Approach. IJAMAD, 1(2), 89-100.
UNEP (2005). Integrated Assessment of the Impact of Trade Liberation. A Country Study on the Nigerian Rice Sector. USDA Foreign Agricultural Service (2015). Grain and Feed annual. GAIN REPORT. Accessed 30 June 2016, available from: http://gain.fas.usda.gov/Recent $\% 20$ GAIN $\% 20$ Publications/Grain\%20and\%20Feed\%20Annual_Lagos_ Nigeria 4-4-2014.pdf

WARDA (2003). Strategy for rice sector revitalization in Nigeria. Project Report -The Nigerian Rice Economy in a Competitive World: Constraints, Opportunities And Strategic Choices. Abidjan: WARDA - The Africa Rice Centre. Retrieved from: http://hubrural.org/IMG/pdf/nigeria_rice_strategy_for_rice_sector_revitalisation.pdf 